\title{
Herpes zoster of the trigeminal nerve with multi-dermatomal involvement: a case report of an unusual presentation
}

\author{
Lorenzo Stefano Pelloni ${ }^{1,2^{*}}$ (D) Raffaele Pelloni ${ }^{3}$ and Luca Borradori ${ }^{1}$
}

\begin{abstract}
Background: Herpes zoster, also known as shingles, results from reactivation of the varicella-zoster virus. It commonly presents with burning pain and vesicular lesions with unilateral distribution and affects the thoracic and cervical sites in up to 60 and 20\% of cases, respectively. The branches of the trigeminal nerves are affected in up to $20 \%$ of cases. Multidermatomal involvement of the trigeminal nerves has been only anecdotally described in immunocompetent subjects.

Case presentation: A 71-year-old previously healthy male presented with grouped vesicular and impetiginized lesions with crusts on the left half of the face of two-weeks duration. The lesions first developed on the left nasal tip and progressively worsened with unilateral appearance of vesicular lesions on the left forehead, face, ala nasi, nasal vestibulum and columella, as well as on the left side of hard and soft palate. The affected edematous erythematous areas corresponded to the distribution of the left ophthalmic (V1) and maxillary (V2) branches of the trigeminal nerve, including the infraorbital and nasopalatine nerves of the maxillary branch responsible for the oral cavity involvement. Viral DNA amplification by polymerase chain reaction confirmed the presence of Varicella zoster virus. The patient was started on oral valaciclovir with rapid recovery.

Conclusions: Among immunocompetent patients, herpes zoster is considered a self-limited localized infection. Our observation provides a rare but paradigmatic example of herpes zoster with involvement of both the ophthalmic and maxillary divisions of the trigeminal nerve in an immunocompetent patient. Immunocompetence status and age-specific screening should be warranted in case of atypical involvement and according to the patient's history, while treatment with antiviral drugs should be rapidily initiated in patients at risk.
\end{abstract}

Keywords: Herpes zoster, Trigeminal nerve, Multidermatomal involvement

\section{Background}

Herpes zoster (HZ), also known as shingles, results from reactivation of the varicella-zoster virus (VZV). It is estimated that there are approximately 1 million new cases per year in the USA [1]. It commonly presents with burning pain and vesicular lesions with unilateral

\footnotetext{
* Correspondence: Iore.pelloni.89@hotmail.com

'Department of Dermatology, University Hospital of Bern, Inselspital, Bern, Switzerland

ENT, Lugano, Switzerland

Full list of author information is available at the end of the article
}

distribution. HZ commonly affects the thoracic and cervical sites in up to 60 and $20 \%$ of cases, respectively. Furthermore, the branches of the trigeminal nerves are involved in up to $20 \%$ of cases [1,2]. Multidermatomal involvement of the trigeminal nerves has been rarely described in immunocompetent subjects [1-4]. We here present a striking case of $\mathrm{HZ}$ with involvement of ophthalmic and maxillary branches of the fifth cranial nerve in an elderly patient.

C C The Author(s). 2020 Open Access This article is licensed under a Creative Commons Attribution 4.0 International License, which permits use, sharing, adaptation, distribution and reproduction in any medium or format, as long as you give appropriate credit to the original author(s) and the source, provide a link to the Creative Commons licence, and indicate if changes were made. The images or other third party material in this article are included in the article's Creative Commons licence, unless indicated otherwise in a credit line to the material. If material is not included in the article's Creative Commons licence and your intended use is not permitted by statutory regulation or exceeds the permitted use, you will need to obtain permission directly from the copyright holder. To view a copy of this licence, visit http://creativecommons.org/licenses/by/4.0/ The Creative Commons Public Domain Dedication waiver (http://creativecommons.org/publicdomain/zero/1.0/) applies to the data made available in this article, unless otherwise stated in a credit line to the data. 


\section{Case presentation}

A 71-year-old male presented with grouped vesicular lesions with crusts on the left half of the face of twoweeks duration. His past medical history was unremarkable. The lesions first developed on the left nasal tip and progressively worsened with unilateral appearance of new maculopapular and vesicular lesions on the left forehead, face, ala nasi, nasal vestibulum and columella, as well as on the left side of hard and soft palate (Fig. 1a, b). The affected edematous areas corresponded to the distribution of the left ophthalmic (V1) and maxillary (V2) branches of the trigeminal nerve, including the infraorbital and nasopalatine nerves of the maxillary branch responsible for the oral cavity involvement.

Ophthalmic examination revealed conjunctival congestion in the left eye with lid edema, but no evidence for herpetic keratitis or uveitis. Viral DNA amplification by polymerase chain reaction (PCR) using smears from forehead and oral mucosa confirmed the presence of VZV, whereas search of Herpes simplex virus type 1 and Herpes simplex virus type 2 by PCR was negative. The rest of the physical examination was normal. Complete blood count, serum electrolytes, hepatic and renal tests were within normal limits. Serological tests for human immunodeficiency virus were negative. The patient subsequently underwent a neck-chest-abdomen-pelvis CT scan, which showed no significant pathologies.

The patient was started on oral valaciclovir $1 \mathrm{~g}$ three times a day, oral paracetamol and topical fucidic acid ointments. Hyaluronic acid eye drops 6-8 times in a day were also prescribed. The patient showed complete recovery within 10 days.

\section{Discussion and conclusions}

$\mathrm{HZ}$ constitutes a reactivation of a latent infection of $\mathrm{VZV}$, an alpha herpes virus [1-7]. VZV, which infects almost $99.5 \%$ of the population of more than 40 years of age has gained access to cranial nerve or dorsal root ganglia during varicella in childhood [1]. The life-time risk of developing $\mathrm{HZ}$ is approximately $30 \%$ [1]. While reactivation of VZV is normally suppressed by a competent immune system [3], risk factors for HZ include aging, psychological stress, immunosuppression such as cancer treatment, direct trauma, surgery and sunburn $[1,4-6]$.

Pain and paresthesia in the involved dermatomes occur usually 2-4 days prior to the development of closely grouped erythematous maculo-papules, which then quickly evolve to vesicular and often impetiginized lesions in areas restricted to the sensitive nerve territory of a dermatome, including mucosal sites as in our case.

Among immunocompetent patients, $\mathrm{HZ}$ is considered a self-limited localized infection. Nevertheless, it may cause significant morbidity and complications. Severe neurological complications, including postherpetic neuralgia (occurs in approximately $20 \%$ of cases), sensory loss and palsy, as well as ocular, cutaneous and visceral complications with viremia may variably occur $[1,5,8-10]$. In contrast to immunodeficient patients, multidermatomal involvement in $\mathrm{HZ}$ is rarely observed in immunocompetent patients. The 1st ophthalmic branch of the fifth cranial nerve is affected about 20 times more often than the 2nd and 3rd branches of the nerve [8].

Noteworthy, only anecdotal reports exist about $\mathrm{HZ}$ affecting two or three branches of the trigeminal nerve [2-4, 6, 9]. In our PubMed search using terms "herpes
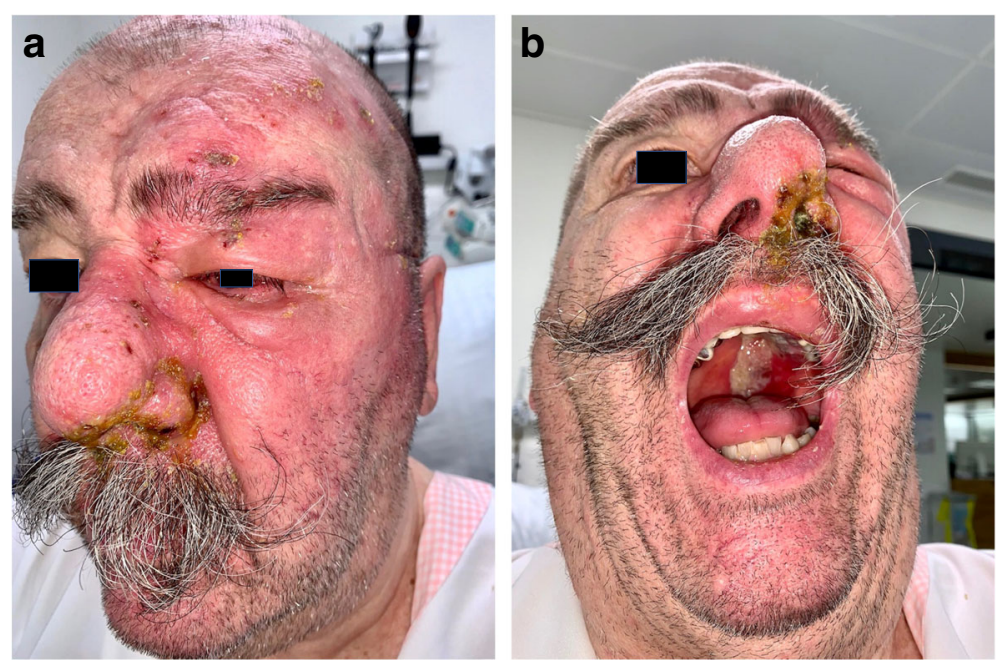

Fig. 1 a Herpes zoster affecting the left ophthalmic and maxillary divisions of the left trigeminal nerve with erythematous vesicular and impetiginized lesions with crusts on the forehead, the periorbital area, the eye, the ala nasi and upper lip. $\mathbf{b}$ Involvement of the left vestibulum nasi and columella with unilateral lesions affecting the oral cavity, including the hard and soft palate 
Table 1 Summary of published cases of multidermatomal herpes zoster affecting the trigeminal nerve

\begin{tabular}{llll}
\hline Authors & Patient age/sex & Affected dermatomes & Comorbidities \\
\hline Dube et al. [2] & $55 / \mathrm{M}$ & V1-3 & None reported \\
Lovell [3] & $57 / \mathrm{F}$ & V1-2 & Rheumatoid arthritis \\
Nair et al. [4] & $68 / \mathrm{M}$ and 50/M & V2-3 and V1-3 & None reported \\
Srivastava et al. [6] & $55 / \mathrm{F}$ & V1-2 & None reported \\
Naveen et al. [9] & 28/M & V1-3 & None reported \\
\hline
\end{tabular}

zoster", "multidermatomal", "trigeminal nerve" and "ophthalmicus" we have only identified 5 reports describing cases with $\mathrm{HZ}$ affecting two or all three branches of the trigeminal nerve (Table 1). Although multidermatomal involvement of the trigeminal nerve branches during $\mathrm{HZ}$ infection has been only very rarely reported in the literature, it is important that clinicians are aware and more familiar with this presentation, which seems not so rare according to specialists who have been practicing long enough.

Practically, in case of ophthalmic zoster, the eye is directly involved in $50-72 \%$ of patients potentially leading to visual impairment, ptosis, pain, keratitis and facial scarring $[2,5]$. In our case, only a conjunctival congestion was present. Presence of lesions on the tip or side of the nose indicate involvement of nasociliary nerve of the ophthalmic branch of the trigeminal nerve, known as Hutchinson's sign [5]. The latter thus warrants a close ophthalmologic evaluation to exclude subsequent ocular involvement. Reactivation of VZV within the maxillary (V2) division may lead to pain and lesions affecting upper lip as well as on the soft and hard palate, while involvement of the mandibular (V3) nerve is associated with manifestations affecting the anterior part of the tongue, floor of oral cavity and buccal mucous membrane [9].

Our observation provides a paradigmatic example of $\mathrm{HZ}$ with involvement of both the ophthalmic and maxillary divisions of the trigeminal nerve in an immunocompetent elderly patient in good general health.

In case of atypical presentations as well as in immunosuppressed patients laboratory testing is indicated to confirm the diagnosis of VZV infection. Immunofluorescence microscopy studies for detection of VZV antigens in tissue smears, viral culture or PCR for VZV DNA assays are useful according to the clinical presentation and practical availability [9].

Different oral antivirals, including valaciclovir, aciclovir, famciclovir and brivudine currently constitute the first therapeutic option based on specific indications and associated comorbidities [10]. Our patient was given oral valaciclovir with complete rapid resolution of the lesions. Nevertheless, in $\mathrm{HZ}$ with involvement of the head with either complicated infection or at risk for a complicated course intravenous aciclovir is recommended [10].
Immunocompetence status and age-specific screening should be warranted in case of atypical involvement and according to the patient's history, while treatment with antiviral drugs should be rapidly initiated in patients at risk for complications.

\section{Abbreviations}

HZ: Herpes zoster; VZV: Varicella zoster virus; PCR: Polymerase chain reaction

\section{Acknowledgements}

We are thankful to the patient for the support given in providing data.

\section{Authors' contributions}

All authors read and approved the final manuscript. LSP: corresponding author, managed the patient and wrote the first draft of the manuscript. RP: co-author, helped in drafting the work. LB: supervised the redaction of the manuscript and critically revised it.

Funding

No funding was obtained for this study.

Availability of data and materials

Data sharing is not applicable to this article as no datasets were generated or analyzed during the current study.

Ethics approval and consent to participate

Not obtained, as it was a case report. Written consent only obtained.

\section{Consent for publication}

Written informed consent was obtained from the patient for publication of this case report and any accompanying images. A copy of the written consent is available for review by the Editor-in-Chief of this journal.

\section{Competing interests}

The authors declare that they have no competing interests.

\section{Author details}

${ }^{1}$ Department of Dermatology, University Hospital of Bern, Inselspital, Bern, Switzerland. ${ }^{2}$ ENT, Lugano, Switzerland. ${ }^{3}$ Universitätsklinik für Dermatologie, Inselspital, Universitätsspital Bern, Freiburgstrasse 34, CH-3010 Bern, Switzerland.

Received: 7 July 2020 Accepted: 26 October 2020

Published online: 30 October 2020

References

1. Harpaz R, Ortega-Sanchez IR, Seward JF. Prevention of Herpes Zoster: Recommendations of the Advisory Committee on Immunization Practices (ACIP). MMWR Recomm Rep. 2008;57:1-30 n. RR-5.

2. Dube S, Pratyush R, Rajshekhar V. Multidermatomal herpes zoster ophthalmicus in an Immunocompetent male. J Clin Ophthalmol Res. 2017; 5(1):38. https://doi.org/10.4103/2320-3897.195308.

3. Lovell B. Trigeminal Herpes Zoster: Early Recognition and Treatment Are Crucial. BMJ Case Rep. 2015;(1). https://doi.org/10.1136/bcr-2014-208673.

4. Nair $P$, Gharote $H$, Singh $O$, Jain-Choudhary P. Herpes Zoster on the Face in the Elderly. BMJ Case Rep. 2014;2014(1). https://doi.org/10.1136/bcr-2013200101. 
5. Vrcek I, Choudhury E, Durairaj V. Herpes zoster Ophthalmicus: a review for the internist. Am J Med. 2017;130(1):21-6. https://doi.org/10.1016/j.amjmed. 2016.08.039.

6. Srivastava RM, Katiyar V, Agrawal S. Posttraumatic Maxillary and Ophthalmic Herpes Zoster in an Immune-Competent Female - A Unique Presentation. Oman J Ophthalmol 13, 1 (2020): 46-47. 10.4103/ojo.OJO_142_2019.

7. Gupta LK, Kuldeep CM, Mittal A, Singhal H. Multidermatomal Herpes Zoster in an Immunocompetent Female. Indian J Dermatol Venereol Leprol. 2005; 71(3):210. https://doi.org/10.4103/0378-6323.16247.

8. Carbone $\mathrm{V}$, et al. Herpes zoster of the trigeminal nerve: a case report and review of the literature. Minerva Stomatol. 2004;53(1-2):49-59.

9. Naveen $\mathrm{KN}$, et al. Herpes zoster affecting all three divisions of trigeminal nerve in an Immunocompetent male: a rare presentation. Indian J Dermatol. 2014;59(4):423. https://doi.org/10.4103/0019-5154.135548.

10. Werner RN, et al. European Consensus-Based (S2k) Guideline on the Management of Herpes Zoster - Guided by the European Dermatology Forum (EDF) in Cooperation with the European Academy of Dermatology and Venereology (EADV), Part 2: Treatment. J Eur Acad Dermatol Venereol. 2017;31(1):20-9. https://doi.org/10.1111/jdv.13957.

\section{Publisher's Note}

Springer Nature remains neutral with regard to jurisdictional claims in published maps and institutional affiliations.

Ready to submit your research? Choose BMC and benefit from:

- fast, convenient online submission

- thorough peer review by experienced researchers in your field

- rapid publication on acceptance

- support for research data, including large and complex data types

- gold Open Access which fosters wider collaboration and increased citations

- maximum visibility for your research: over $100 \mathrm{M}$ website views per year

At BMC, research is always in progress.

Learn more biomedcentral.com/submissions 